\title{
加齢による下肢筋量の低下が歩行能力に及ぼす影響
}

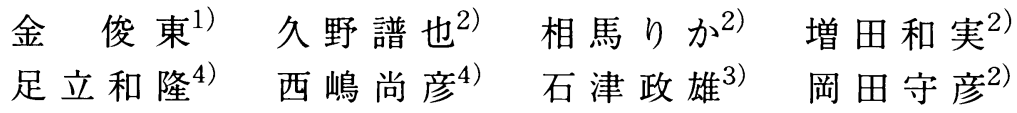

\section{RELATIONSHIP BETWEEN REDUCTION OF HIP JOINT AND THIGH MUSCLE AND WALKING ABILITY IN ELDERLY PEOPLE}

\author{
JunDong Kim, Shinya Kuno, Rika Soma, Kazumi Masuda, Kazutaka Adachi, \\ TAKAHIKo Nishimima, Masao ISHIzU and MoRihiKo OKada
}

\begin{abstract}
The purpose of this study was to investigate the hypothesis that the reduction in walking ability is due to muscle atrophy in the lower limb muscles with aging using equational structure modeling as well as investigate the influence of muscle on walking ability. The subjects consisted of 127 persons ( 57 males and 70 females) aged 20 84 year, who were grouped into 6 age brackets of $20 \sim 39$, $40 \sim 49,50 \sim 59,60 \sim 69,70 \sim 74$, and 75 or older. Using MRI, muscle cross-sectional area was measured on psoas major and thigh muscle (divided into extensor and flexor). For walking patterns, each subject walked along a 7-m walking passage at normal speed for VTR-recording of the motion. The resulting pictures were used to analyze stride length, trunk inclination and walking speeds. Walking speeds showed a statistically significant decrease in value from the 50's age group in males and the 60's age group in females when compared with the $20 \sim 39$ age bracket $(\mathrm{p}<0.05)$. In males, a significant co-relationship was observed only between the muscle cross-sectional area of thigh extensor and walking speed $(\mathrm{p}<0.01)$ while in females, a significant co-relationship was found between the muscle cross-sectional area of psoas major $(\mathrm{p}<0.001) /$ thigh muscle extensor $(\mathrm{p}<0.01)$ and walking speed. These results indicate that the muscle atrophy with aging in psoas major and thigh muscle extensor is a factor responsible for the decrease in walking speed. Meanwhile, a differ. ence in sex was observed between the muscle cross-sectional area of psoas major and walking speed. It was considered that the muscle atrophy rate of the female's psoas major being higher than the male's influenced this. Furthermore, it was suggested possibility that the decline of walking ability is due to decreased muscle mass of the lower limbs with aging.
\end{abstract}

(Jpn. J. Phys. Fitness Sports Med. 2000, $49: 589 \sim 596)$

key word : aging, muscle cross-sectional area, psoas major, walking speed

\section{I. 緒}

加齢現象の一つとして，歩行機能が低下する. 若年者と高齢者の歩行能力を比較した多くの研究 では，一般に若年者がより高い能力を持つことが
示されている ${ }^{5,14,16)}$. 高齢者の歩行の特徴とし ては，歩幅の減少，歩調の低下，両脚の支持時間 の延長及び股関節，膝関節及び足関節における運 動域の減少などがあげられ，特に歩行速度の低下 が顕著である。また，このような歩行能力の低下

\footnotetext{
1) 筑波大学大学院博士課程体育科学研究科 † 305-8574 茨城県つくば市天王台1-1-1

2) 筑波大学先端学際領域研究センター 下 305-8577 茨城県つくば市天王台1-1-1

3) 大洋村役場 \% 311-2113 茨城県鹿島郡大洋村上幡木1500-2

4) 筑波大学体育科学系 厂305-8574 茨城県つくば市天王台1-1-1
}

Doctoral Program in Health and Sport Sciences, University of Tsukuba, 1-1-1 Ten-nodai, Tsukuba, Ibaraki (305-8574) Center for Tsukuba Advanced Research Alliance, University of Tsukuba, 1-1-1 Ten-nodai, Tsukuba, Ibaraki (305-8577) Mayor of Taiyo Village, 1500-2 Taiyomura, Kasimagun, Ibaraki (311-2113)

Institute of Health and Sport Sciences, University of Tsukuba, 1-1-1 Ten-nodai, Tsukuba, Ibaraki (305-8574) 
には, 神経系調節能力の低下, 骨の弱化, 筋力の 低下などが原因となっていることが報告されてい $ろ^{2,6,17)}$ 。これらのうち，筋力の低下に関しては 筋力が筋の横断面積と比例することから, 加齢に 伴う筋量の隇少がその主要因といえよう.

ヒトの歩行に関する筋電図学的な研究による と, 歩行能力は下肢筋の筋力と密接な関係にある ことが示されている ${ }^{19,27)}$. しかしながら, 最近, 歩行時のヒトの笳活動は大腿部および下腿部と いった下肢筋群のみではなく, 股関節屈曲に関与 する大腰筋の役割も重要であることが指摘され 12)，大腿部および下腿部の筋活動の検討だけで は，歩行能力を評価するのに十分とは言えない可 能性が考えられる. 事実, Andersson et al. ${ }^{1)}$ は, 歩行時の大腰筋の働きを検討し, 歩行時における 筋電図の振幅が大腿部のみではなく大腰筋におい ても観察され, 特に歩行速度の増加にともなって さらに激しくなることを示している，また，我々 は, 160名の20歳代から80歳代の男女を対象にし て，MRIにより大腰筋の筋横断面積を検討した ところ, 男女とも70歳代では20歳代に比べて約 40\%減少することを明らかにした ${ }^{11)}$ 。これまでの 先行研究を考慮すると, 高㱓者における歩行能力 の低下に及ほす重要な要因として，筋量の減少に よる歩行速度の低下があげられるが,これらの2 つ要因の関係を直接的に検討した研究は我々の知 る限り他にはみられない。

そこで本研究では, 加齢により股関節及び大腿 部の筋横断面積が減少し, その結果歩行能力の低 下をもたらすとの仮説を検討すること，及びそれ
らの筋群の中で歩行能力により強い影響を及ほす 筋についても検討することを目的とした.

\section{II. 方法}

\section{A. 被検者}

被検者には，20～84歳までの男性57名，女性70 名の計127名を用いた。年龄別の内訳, 身長及び 体重を表 1 に示した，身長において男女とも60 69歳代，70〜74歳代及び75歳以上の群では，20〜 39歳代に比べて，それぞれ有意に低值を示した。 体重においては, 男性の70 74歳代及び75歳以上 の群が20～39歳代に比べて, それぞれ有意に低值 を示したが，女性において各年齢群の間に有意な 差は認められなかった。

全ての被検者に実験の主旨, 内容および危険性 についてあらかじめ書面と口頭により説明し, 参 加の同意を得た. なお, 本研究は東京大学大学院 生命環境科学系倫理委員会の承認を得た.

\section{B. 磁気共鳴映像法: magnetic resonance imaging (MRI) による筋横断面樌の測定}

1. 大腰筋横断面積

MRI の測定は, 筑波大学附属病院に設置され ている臨床用 $1.5 \mathrm{~T}$ の超電導 MRI 装置 (Signa, GE 社製，USA）を用いた．測定に用いた撮影条件 は，パルスシークエンスはスピンエコー法により 繰り返し時間 $340 \mathrm{msec}$, エコー時間 $12 \mathrm{msec}, 2$ Nex で, 腹部の横断画像を 1 枚得た。撮影位置は, 被検者間の横断面積の比較が可能となるように, 生体上において腸骨稜を確認し，その位置の横断

Table 1. Physical characteristics in each age group.

\begin{tabular}{|c|c|c|c|c|c|c|}
\hline \multirow[t]{2}{*}{ Age group } & \multicolumn{3}{|c|}{ Male } & \multicolumn{3}{|c|}{ Female } \\
\hline & $\mathrm{n}$ & Height(cm) & Weight(kg) & $n$ & Height(cm) & Weight(kg) \\
\hline $20-39$ & 14 & $170.5 \pm 6.6$ & $67.8 \pm 9.8$ & 10 & $157.3 \pm 3.9$ & $52.5 \pm 3.4$ \\
\hline $40-49$ & 6 & $168.6 \pm 4.0$ & $68.5 \pm 11.4$ & 5 & $155.1 \pm 6.5$ & $56.5 \pm 3.0$ \\
\hline $50-59$ & 5 & $165.1 \pm 6.2$ & $70.3 \pm 9.3$ & 17 & $152.9 \pm 5.4$ & $56.0 \pm 2.1$ \\
\hline $60-69$ & 18 & $160.1 \pm 4.2^{\star \star}$ & $63.1 \pm 8.0$ & 25 & $149.2 \pm 6.4^{\star \star}$ & $54.5 \pm 1.5$ \\
\hline $70-74$ & 7 & $161.2 \pm 4.0^{\star \star}$ & $58.9 \pm 8.7^{\star}$ & 8 & $145.5 \pm 4.1^{\star \star}$ & $51.3 \pm 2.4$ \\
\hline $\begin{array}{l}75- \\
\text { Total }\end{array}$ & $\begin{array}{c}7 \\
57\end{array}$ & $156.8 \pm 6.4^{\star \star}$ & $59.3 \pm 8.1^{\star}$ & $\begin{array}{c}5 \\
70\end{array}$ & $141.5 \pm 6.1^{\star \star}$ & $51.1 \pm 3.2$ \\
\hline
\end{tabular}

Values are mean \pm SD. $\quad \star_{\mathrm{P}}<0.05, \star^{\star} \mathrm{P}<0.01$ vs $20 \sim 39$ age group. 
画像を得られるよう設定した。被検者は, MRI 装置内において仰臥位で固定した。

得られた画像は, 直ちにMRI 専用のフィルム 上にプリントした。横断面積の測定は，フィルム 上に左右 2 つの大腰筋像を同定した後, トレーシ ングペーパーにトレースし，それをスキャナーで コンピュータに取り込み, NIH imaging を用いて 横断面積を測定した.なお, 大腰筋横断面積のデー

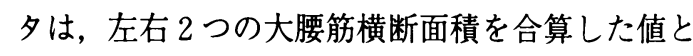
した.

\section{2. 大腿部の筋横断面積}

大腿部の筋横断面積は, あらかじめ下半身の冠 状断像を撮影し，その像より右脚の大転子と脛骨 頭の外側顆間結節を同定した。そして外側顆間結 節から近位方向へ $70 \%$ の距離にあたる位置を決定 し,この位置より遠位方向へ等間隔に右脚の横断 像を撮影した。繰り返し時間 $900 \mathrm{msec}$, エコー 時間 $20 \mathrm{msec}$, 撮像領域 $24 \mathrm{~cm} \times 24 \mathrm{~cm}$, 厚さ 10 $\mathrm{mm}$, マトリックス $256 \times 128$, 励起 1 回の条件で あった。スライス間隔は $12 \mathrm{~mm}$ で遠位方向に 15 枚の横断像を連続的に撮影した。撮像の際には, 完全に膝関節を伸展させ，大腿部がベッドに触れ ないように注意を払った。得られた画像から大腿 四頭筋, ハムストリング (大腿二頭筋, 半腱様筋, 半膜様筋) および内転筋群 (大内転筋, 短内転筋, 長内転筋)の各横断面積を算出した.

\section{C. 歩行動作}

歩行動作は, 被検者の左側の耳珠, 大転子, 膝 関節, 外果, 踵, 第 5 中足骨遠位端にマーカーを 取り付けた状態で, 実験室内の $7 \mathrm{~m}$ 歩行路上を 歩行させた.そして，その動きをビデオカメラ (SONY 製 XC-009)を用いて撮影した後, 分析し た. 歩行速度は, 被検者の主観的判断による “普 通”の速度とし，十分に説明を行った．歩行は 3 回試行して，その平均の值を得た。各マーカーの 動きは, 被検者の左側面直角方向から二次元動作 測定システム (応用計測研究所製 Quick-MAG system 3)を使用して測定, 記録した. 各マーカー の位置座標から, 歩行速度などを 1 歩行周期ごと に算出した.
ビデオでの分析項目は歩行速度, 上体の前傾角 度および歩幅である．歩行速度は 1 分あたりの距 離 $(\mathrm{m} / \mathrm{min}) て ゙$, 上体の前傾角度は, 股関節の最大 屈曲時における角度を測定した。

\section{D. 統計処理}

大腰筋横断面積, 大腿部の筋横断面積と歩行速 度, 歩幅, 歩行時の前傾角度の各変数間の関連性 を検討するために, ピアソンの相関係数を求めた。 各年代間の各筋横断面積, 歩行速度, 歩幅及び前 傾角度の平均値の差の検定には, 一元配置の分散 分析を用い，有意性の認められた場合, post-hoc の検定をFisher の $\mathrm{z}$ 変換法にて行った。 なお, 統計量はすべて平均值士標準偏差で示し, 有意水 準は危険率 $5 \%$ 未満とした.

また, 本研究の仮説構造を検証するために, 多 重指標モデルを用いた共分散構造分析 (Equational Structure Modeling : ESM $)^{7,13)}$ を行った. 仮説モ デルの適合度指標には GFI (Goodness of fit index), AGFI (Adjusted goodness of fit index), CFI (Comparative fir index) ${ }^{7)}$, NFI(Normed fit index), RMSEA (Root Mean Square Error of Approximation), $\chi$ (カイ) 2 乗検定の確率を用い た.モデル修正は, パス係数の有意性, 修正指数 (Amos $4.0 \mathrm{~J})$ に基づいて行い，モデル修正に伴う モデル適合度の変化は AIC (Akaike Information Criterion)によって確認した. GFI および AGFI は, 推定された共分散構造と標本分散行列とのく いちがいの程度により適合度を示し，これらの值 が1に近いときに良い当てはまりを示す。回帰分 析では, GFI は重相関係数, AGFI は自由度調整 済みの重相関係数に対応する. 経験的に推定する パラメー夕数が 30 未満の場合では 0.90 以上を優良 適合と判断する.NFI およびCFIは，モデルが 独立モデルと飽和モデルとを結ぶ直線上の位置に より適合度を示し，1に近いときに良い当てはま りを示す ${ }^{7)}$. RMSEA は、モデルの複雑さによる 見かけ上の適合度の上昇を調整する適合度指標の 1つである．0.08以下であれば適合度が高いとさ れており，0.10以上であればモデルを採択すべき ではないとされている. AIC は相対的なモデル 
の良さを示す指標であり，モデル間の比較に適し ている．以上の統計解析にはアプリケーションソ フトウェアAMOS 4.0 J および SPSS 9.0 J を用い $た^{24)}$.

\section{III. 結果}

表 2 に, 年代群別の各筋横断面積と歩行能力を 表す各変数を示した. その結果, 男性の大腰筋と 大腿部伸筋群, 屈筋群の筋横断面積においては20 ～39歳代に比べて60歳代からそれぞれ有意に低值 を示した。 また, 歩行速度は50歳代から, 歩幅は 70〜74歳群から, 前傾角度は75歳以上の群で20 39歳代に比べてそれぞれ有意に低値を示した。 一 方, 女性では大腰筋と大腿部伸筋群の筋横断面積 において 20～39歳代に比べて 50歳代からそれぞれ 有意に低值を示した．なお，20３9歳代に比べて 歩行速度及び歩幅は60歳代から, 前傾角度は75歳 以上の群で有意に低值を示した。

表 3 は男女における, 各測定項目の間の相関係 数を示したものである. 男性において伸筋群の筋
横断面積と歩行速度との間には有意な相関関係 $(\mathrm{p}<0.01)$ が認められたが，大腰筋及び屈筋群の 筋横断面積と歩行速度との間に有意な相関関係は 認められなかった。女性では大腰筋 $(\mathrm{p}<0.01)$ 及 び伸筋群 $(\mathrm{p}<0.01)$ の筋横断面積と, 歩行速度と の間に有意な相関関係が認められた。しかしなが ら, 男性と同様に屈筋群の筋横断面積と歩行速度 との間には有意な相関関係は認められなかった。 また，大腰筋横断面積と歩幅の関係において，男 女ともに有意な相関関係が認められた (男 : $\mathrm{p}<$ 0.05 , 女 : $p<0.01)$. 大腰筋横断面積と前傾角度 との間にも，男女とも有意な相関関係が認められ た $(\mathrm{p}<0.05$ ，それぞれ)．伸筋群の筋横断面積と 歩幅の関係においても，男女ともに有意な相関関 係が認められた $(\mathrm{p}<0.01$ ，それぞれ).

図 1 および図 2 には，加齢に伴う筋量の低下が 歩行能力を低下させるという因果モデルについて の共分散構造分析結果を男女別に示した．男性の モデルの適合度指標では, AGFI は0.895と0.9を 下回ったものの, GFI は0.955, CFI は1.000,

Table 2. Muscle CSA and walking ability in each age group.

\begin{tabular}{|c|c|c|c|c|c|c|}
\hline \multicolumn{7}{|c|}{ Male } \\
\hline Age group & $\begin{array}{c}\text { Psoas major } \\
\left(\mathrm{cm}^{2}\right)\end{array}$ & $\begin{array}{c}\text { Extensors } \\
\left(\mathrm{cm}^{2}\right)\end{array}$ & $\begin{array}{l}\text { Flexors } \\
\left(\mathrm{cm}^{2}\right)\end{array}$ & $\begin{array}{c}\text { Walking speed } \\
(\mathrm{m} / \mathrm{min})\end{array}$ & $\begin{array}{c}\text { Stride length } \\
\text { (cm) }\end{array}$ & $\begin{array}{c}\text { Trunk inclination } \\
\text { (deg) }\end{array}$ \\
\hline $20-39$ & $30.2(4.8)$ & $68.8(11.2)$ & $70.3(8.1)$ & $74.5(7.5)$ & $133.2(12.1)$ & $3.4(2.0)$ \\
\hline 40.49 & $25.3(6.4)$ & $62.8(7.4)$ & $63.6(11.2)$ & $69.7(7.8)$ & $124.9(11.6)$ & $4.2(1.5)$ \\
\hline $50-59$ & $25.7(7.8)$ & $62.3(8.0)$ & $66.5(12.7)$ & $60.5(14.0)^{\star}$ & $117.8(15.3)$ & $4.3(4.9)$ \\
\hline $60-69$ & $20.5(3.3)^{\star \star}$ & $49.3(5.5)^{\star \star}$ & $54.9(8.3)^{\star \star}$ & $66.8(11.0)^{\star}$ & $124.1(15.1)$ & $4.2(2.3)$ \\
\hline $70-74$ & $19.5(7.7)^{\star \star}$ & $45.4(5.9)^{\star \star}$ & $48.1(11.6)^{\star \star}$ & $54.9(16.9)^{\star \star}$ & $106.7(22.1)^{\star \star}$ & $5.1(3.9)$ \\
\hline 75 & $17.8(4.0)^{\star \star}$ & $43.1(6.1)^{\star \star}$ & $50.5(9.5)^{\star \star}$ & $53.0(6.9)^{\star \star}$ & $94.3(17.7)^{\star \star}$ & $9.5(6.7)^{\star \star}$ \\
\hline \multicolumn{7}{|c|}{ Female } \\
\hline Age group & $\begin{array}{c}\text { Psoas major } \\
\left(\mathrm{cm}^{2}\right)\end{array}$ & $\begin{array}{c}\text { Extensors } \\
\left(\mathrm{cm}^{2}\right)\end{array}$ & $\begin{array}{l}\text { Flexors } \\
\left(\mathrm{cm}^{2}\right)\end{array}$ & $\begin{array}{c}\text { Walking speed } \\
\text { (m/min) }\end{array}$ & $\begin{array}{l}\text { Stride length } \\
\text { (cm) }\end{array}$ & $\begin{array}{c}\text { Trunk inclination } \\
\text { (deg) }\end{array}$ \\
\hline $20-39$ & $17.4(2.9)$ & $45.8(4.0)$ & $40.9(4.6)$ & $76.2(8.0)$ & $122.6(10.5)$ & $2.5(2.9)$ \\
\hline $40-49$ & $15.1(2.0)$ & $43.4(5.5)$ & $41.5(4.0)$ & $66.9(8.8)$ & $114.4(9.2)$ & $1.4(1.1)$ \\
\hline $50-59$ & $12.8(3.2)^{\star \star}$ & $38.4(6.5)^{\star \star}$ & $38.7(6.4)$ & $74.3(12.1)$ & $115.7(8.6)$ & $2.5(3.2)$ \\
\hline $60-69$ & $12.0(2.5)^{\star \star}$ & $37.1(5.1)^{\star \star *}$ & $39.9(8.5)$ & $64.7(9.6)^{\star \star}$ & $111.6(10.9)^{\star}$ & $3.1(3.2)$ \\
\hline $70-74$ & $11.0(1.5)^{\star \star}$ & $33.9(4.6)^{\star \star}$ & $36.4(6.9)$ & $60.5(8.2)^{\star \star}$ & $101.2(14.2)^{\star \star}$ & $4.8(4.3)$ \\
\hline $75-$ & $8.5(1.4)^{\star \star}$ & $33.6(5.9)^{\star *}$ & $34.0(6.5)$ & $53.9(5.3)^{\star \star}$ & $100.7(16.7)^{\star \star}$ & $7.0(6.9)^{\star}$ \\
\hline
\end{tabular}

Values are mean. $\left(\mathrm{l}=\mathrm{SD} . \quad \star_{\mathrm{P}}<0.05, \star_{\mathrm{P}}<0.01\right.$ vs $20 \sim 39$ age group. 
Table 3. A coefficient of correlation between the each parameters.

【Male】

\begin{tabular}{|c|c|c|c|c|c|c|c|c|}
\hline & Age & & & & & & & \\
\hline Height & $-0.690^{\star \star}$ & Height & & & & & & \\
\hline Weight & $-0.337^{\star}$ & $0.547^{\star \star}$ & Weight & & & & & \\
\hline Walking speed & $-0.530^{\star *}$ & $0.412^{\star \star}$ & 0.204 & Walking speed & & & & \\
\hline Stride length & $-0.574^{\star \star}$ & $0.538^{\star \star}$ & 0.220 & $0.722^{\star \star}$ & Stride length & & & \\
\hline Trunk inclination & $0.364^{\star \star}$ & $-0.263^{\star}$ & -0.211 & $-0.305^{*}$ & $-0.484^{\star \star}$ & Trunk inclination & & \\
\hline Psoas major & $-0.668^{\star \star}$ & $0.554^{\star \star}$ & $0.554^{\star \star \star}$ & 0.211 & $0.284^{\star}$ & $-0.271^{\star}$ & Psoas major & \\
\hline \begin{tabular}{|l} 
Extensors \\
\end{tabular} & $-0.809^{* \star}$ & $0.585^{\star \star}$ & $0.530^{\star \star *}$ & $0.362^{\star \star}$ & $0.452^{\star \star}$ & $-0.331^{\star}$ & $0.654^{\star *}$ & Extensors \\
\hline Flexors & $-0.646^{\star \star}$ & $0.547^{\star \star}$ & $0.600 * \star$ & 0.237 & $0.305^{*}$ & -0.225 & $0.648^{\star \star \star}$ & $0.699^{\star \star}$ \\
\hline
\end{tabular}

【Female】

\begin{tabular}{|c|c|c|c|c|c|c|c|c|}
\hline & Age & & & & & & & \\
\hline Height & $-0.575^{\star \star}$ & Height & & & & & & \\
\hline Weight & -0.038 & $0.445^{\star \star}$ & Weight & & & & & \\
\hline Walking speed & $-0.477^{\star \star}$ & $0.449^{\star \star}$ & -0.089 & Walking speed & & & & \\
\hline Stride length & $-0.492^{\star \star}$ & $0.611^{\star \star}$ & 0.107 & $0.736^{* \star}$ & Stride length & & & \\
\hline Trunk inclination & $0.241^{\star}$ & -0.236 & -0.011 & -0.188 & -0.132 & Trunk inclination & & \\
\hline Psoas major & $-0.639^{\star *}$ & $0.491^{\star \star}$ & 0.123 & $0.459^{\star \star \star}$ & $0.419^{\star \star}$ & $-0.304^{\star}$ & Psoas major & \\
\hline Extensors & $-0.595^{\star \star}$ & $0.408^{\star \star *}$ & 0.191 & $0.348^{\star \star *}$ & $0.347^{\star \star \star}$ & $-0.301^{\star}$ & $0.523^{\star \star}$ & Extensors \\
\hline Flexors & -0.198 & 0.228 & $0.319^{\star \star}$ & 0.136 & $0.260^{\star}$ & $-0.286^{\star}$ & $0.334^{\star \star}$ & $0.495^{\star \star}$ \\
\hline
\end{tabular}

$\star_{\mathrm{p}<0.05, \star_{\mathrm{p}}<0.01}$

NFI は 0.959, といずれも 0.9 以上を示し, RMSEA は0.000, カイ 2 乗検定は有意ではなく, 因果モデルは十分な適合であると判断された。加 齢 $\rightarrow$ 筋量間のパス係数は -0.88 , 筋量 $\rightarrow$ 歩行能力 間のパス係数は 0.73 を示し，加齢 $\rightarrow$ 筋量 $\rightarrow$ 歩行能 力間では統計的に有意な高い因果関係を示した $(\mathrm{p}<0.05)$ ．筋量と各筋群の筋横断面積との間で
は0.76 0.90, 歩行能力と各歩行パフォーマンス 変数との間ではー0.50〜0.89, といずれも統計的 に有意なパス係数を示した $(\mathrm{p}<0.05)$.

女性では, GFI は0.969, AGFI0.908, CFI は 1.000, NFI は0.956, といずれも0.9以上を示し, RMSEA は 0.000 , カイ 2 乗検定は有意ではなく, 男性の因果モデル同様に十分な適合であると判断

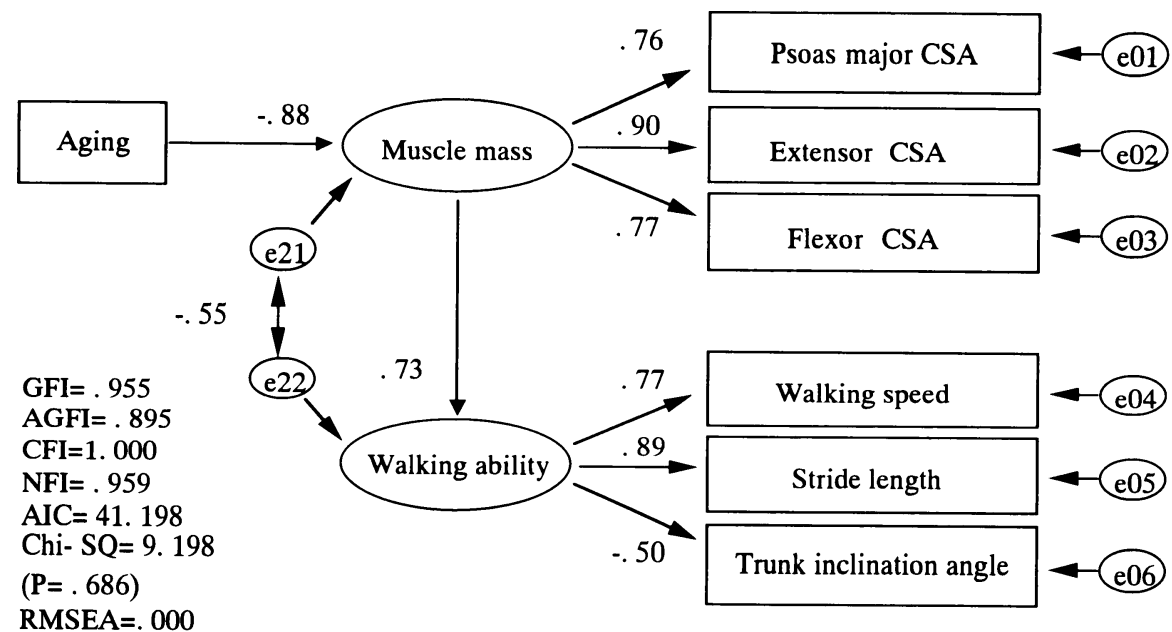

Fig. 1. Causal model of walking ability on muscle atrophy with aging for male. 


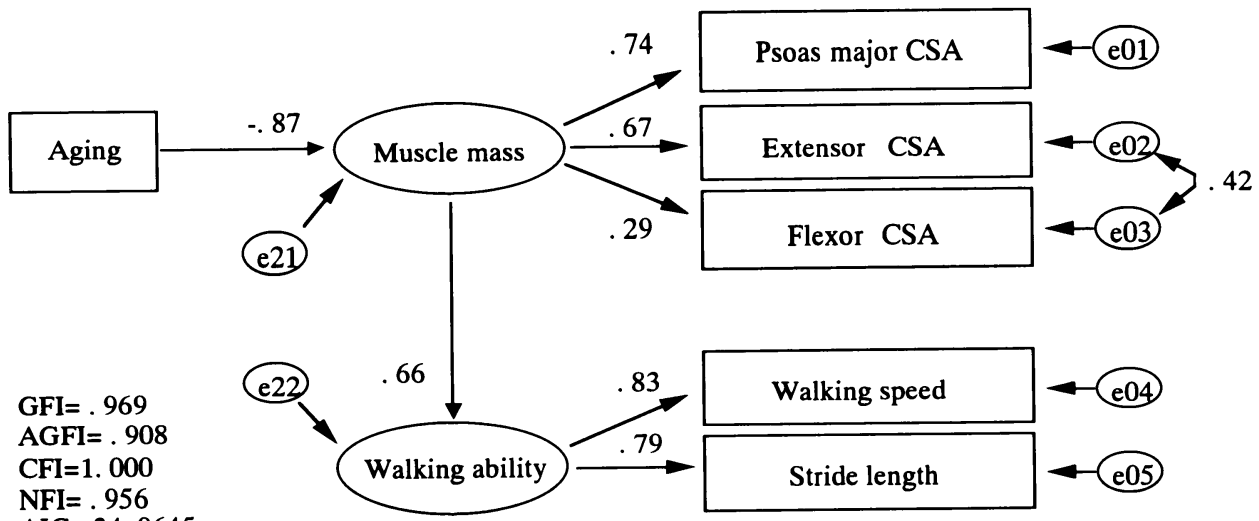

$\mathrm{AIC}=34.9645$

Chi- $S Q=6.965$

$(\mathrm{P}=$. 433)

RMSEA $=.000$

Fig. 2. Causal model of walking ability on muscle atrophy with aging for female.

された，加齢 $\rightarrow$ 筋量間のパス係数は -0.87 ，筋量

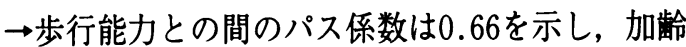
$\rightarrow$ 筋量 $\rightarrow$ 歩行能力間では, 男性モデル同様に, 統 計的に有意な高い因果関係を示した $(\mathrm{p}<0.05)$. 筋量と各筋群の筋横断面積との間では 0.29 0.74 , 歩行能力と各歩行パフォーマンス変数との 間では $0.79 ， 0.83$ といずれも統計的に有意なパス 係数を示した $(\mathrm{p}<0.05)$ 。また, 歩行能力と歩行 時前傾角度間のパス係数は統計的に有意ではな かったので, 因果モデルから削除した。

\section{N. 考察}

これまで高齢者を対象とした研究の中で，加齢 による筋の量的変化に関する検討は多くなされて きている3 ${ }^{3,4,10,11)}$. 高齢者の歩行に関する研究 については，バイオメカニクスの手法を用いた歩 行動作を検討している研究が多くみられる ${ }^{6,14)}$. しかしながら，特に高齢者に扔いて下肢筋の量的 な状態が歩行能力に与える影響は大きいと予想さ れるにも関わらず, 歩行動作と下肢筋量との関連 性を同時に检討した研究は我々の知る限り他には みられないのが現状である．また，いくつかの高 齢者の歩行に関する研究においては，そのほとん どが大腿部あるいは下腿部の筋のみに着目したも のである ${ }^{19,27)}$. 一方, 最近の先行研究 ${ }^{1,12)} に よ$ ると，股関節に位置する大腰筋が歩行時の股関節
屈曲(脚の前方への振り出し)の原動力となってい ることが明らかにされている。 しかしながら，加 齢に伴う大腰筋の筋量と歩行能力との関連を検討 した研究についても, 我々の知る限り他にはみら れない，そこで本研究の目的は，従来から検討さ れている大腿部に加えて歩行に一定の役割を果た すと考えられる大腰筋についても検討対象とし， これらの筋量の低下がヒトの歩行能力の低下にど のような影響を及はしているのかについて検討す ることであった.

これまでの歩行能力における加齢の影響に関す る研究は, 歩行速度, 歩幅, 歩調及び各関節角度 などが検討されてきた。これらの研究によって示 された高龄者の歩行の特徽としては, 高龄者は若 年者に比べて歩行速度の低下を示し, その低下は 歩幅の減少に大きく依存することが示されてい $3^{6,14)}$. 本研究においても，これまでの研究 から得られた結果と同様な高齢者の歩行の特徴 (歩行速度, 前傾角度, 歩幅の低下) が認められ $た^{5,6,14,20)}$ ．歩行速度は，若年者 $(20 \sim 39$ 歳代 $)$ と比べて男性においては50歳代，女性では60歳代 から統計的に有意に遅延を示した(表 2)。また， 歩幅も同梯に男女とも60歳代あるいは70歳代にお いて若年者より低值を示している，いくつかの研 究により，歩幅の減少は脚筋力の低下と密接な関 係にあることがこれまでに示唆されている16,17). 
このことは，歩幅の低下をきたす要因に筋の量的 状態が大きく影響することを示唆するものであ る. そこで本研究では, 歩行の主働筋と思われる 筋群の筋横断面積と歩行速度との関係を検討し た。その結果, 男性では大腿部の伸筋群と女性で は大腰筋及び大腿部・伸筋群と歩行速度との間に それぞれ有意な相関関係が認められた。一方, 各 筋群と歩幅との間では, 男女とも大腰筋・伸筋群 及び屈筋群のいずれともそれぞれ有意な相関関係 が認められた。これらの結果は, 筋量の低下が歩 幅の減少を引き起こし, 最終的に歩行速度の低下 をもたらすという図式を示唆するものであった。 ヒトの歩行時に脚の動作を機能面から検討した研 究によると, 大腿部の伸筋群の大きな役割は, 片 脚を離地させる時に反対脚及び体幹をしっかり固 定させることである ${ }^{1)}$. 一方, 大腰筋は脚を前方 に振り出す時に主に動員されている ${ }^{1)}$. したがっ て，これらの筋量が減少すると筋力の低下がおこ るため, 伸筋群の役割である体幹支持において安 定感がなくなり, 一定の歩幅をとることが困難に なるものと考えられる.また, 大腰筋量の減少は, 大腰筋の役割である脚の前方への振り出しの距離 が短くなるため, 同じく歩幅の減少をもたらすも のと予想される。したがって，これらの筋量が減 少し，それらの複合的な要因によって歩幅の減少 が引き起こされるのであろう.

この 3 つの筋群の加齢に伴う筋横断面積の隇少 と歩行速度あるいは歩幅における低下への影響度 において, 男女差が認められた。単純相関関係及 び共分散構造分析のいずれにおいても, 男性では 伸筋群の低下度が他の筋群に比べて影響度が大き く, 次いで大腰筋, 屈筋群という傾向が認められ た(図 1)。一方, 女性では大腰筋量の減少の影響 度が最も大きく, 次いで伸筋群という順序であり, 屈筋群ではほとんど影響を及ほしていないことが 示された(図 2 )。このような男女差がみられた正 確な理由については不明であるが, 女性では20歳 代からの大腰筋横断面積の低下度が男性に比べて 75歳代で約 $10 \%$ 高いこと, 一方, 屈筋群の低下度 は逆に約10\%低いことが影響したものと考えられ る.
歩行機能と大腰筋の関係に関する研究は, 筋電 図による検討が古くから報告されているが8,15), これらの研究では大腰筋の役割として姿勢の保持 に用いられていることを認めただけであった。こ れに対して最近, MRI を用いて大腰筋の機能に 関する検討を行った名倉たちは，この筋が直立2 足歩行を行うヒトの骨盤と股関節を安定させ, 歩 行時の股関節屈曲に大きく関与する主動筋である ことを示した ${ }^{12)}$. 本研究で大腰筋に着目した大 きな理由も，大腰筋が脚を引き上げる動作に関係 があるにも関わらず，加齢に伴う歩行能力の変化 との関連性を調べた研究はみられなかったためで ある。

本研究の仮説を総合的に検討するために，仮説 をモデル化分析する共分散構造分析を行った(図 $1,2)$. 共分散構造分析は本研究の「加齢によ り下肢筋の筋横断面積が減少し, その結果歩行能 力が低下するとの仮説」のような変数間の因果関 係を検討するのに適切な統計方法 ${ }^{21)}$ であると考 えられる，実際，男女ともに加齢によって大腰 筋及び大腿部の筋量が減少する因果関係は高い パス係数から認められており（男； -0.88 , 女； $-0.87)$, 各部位の筋量が減少した結果, 歩行能 力が低下するという因果関係にもパス係数は高 かった(男; 0.73, 女；0.66)。この結果は, 歩行 能力の低下原因が「加齢」そのものより直接的に 加齢に伴う筋量の低下にあることを示しており， 適合度指標である GFI 及び AGFI の適合度が男 女とも 1 に違いほど高いことから，我々の仮説モ デルは信頼性が高いことが認められた。

\section{V. 要 約}

本研究を要約すると, 加歯に伴う歩行能力と歩 行時に動員される大腰筋と大腿部の筋横断面積と の関係を検討した結果，1）大腰筋の筋横断面積 と歩行速度の間には，女性において有意な相関関 係がみられた。 2) 大腿部伸筋群の筋横断面積と 歩行速度の間には男女とも有意な相関関係がみら れた。しかしながら, 屈筋群の筋横断面積と歩行 速度との間には男女とも一定な関係は認められな かった. 3）大腰筋及び伸筋群の筋横断面積と歩 
幅との間には，男女ともに有意な相関関係がみら れた。 また，加齢による筋量の低下が歩行能力の 低下を導いていることを共分散構造分析によって 証明した。

以上の結果から, 加齢に伴う大腰筋と大腿部伸 筋群の筋量の低下は, 歩行速度の低下に大きな影 響を及ほす可能性が示唆された。これらの筋群の トレーニング活動を行うことによって，歩行能力 は向上させることができると考えられる，そこ で，今後の課題として，高齢者に対してトレーニ ングによる大腰筋および大腿部筋量の変化が歩行 動作に及ほす影響について検討する必要性が示唆 された。

本研究は, 平成 9 年度発足の筑波大学 TARA プロ ジェクト(代表; 岡田守彦) 及び平成11年度科学技術 庁・科学技術振興調整費 (代表; 村上和雄) による研 究 (SATプロジェクト)の一部である.

（受理日 平成12年 8 月10日）

\section{参考 文 献}

1) Andersson, E. A., Nilsson, J. and Thorstensson, A. Intramusclar EMG from the hip flexor muscles dur. ing human locomotion. Acta Physiol. Scand., (1997), 161, 361-370.

2) Bassey, E. J., Bendall, M. J. and Pearson, M. Muscle strength in the triceps surae and objectively mea. sured customaty walking activity in men and women over 65 years. Clinical Science, (1988), 74. 85-89.

3) Fisher, N. M., Pendergast, D. R. and Calkins, E. C. Maximal isometric torque of knee extension as a function of muscle length in subjects of advancing age. Arch. Phys. Med. Rehabil., (1990), 71, 729-734.

4) Frontera, W. R., Carol, N., Meredith, C. N., Kevin, P. O., Howard, R. G. and Evans, W. J. Strength con ditioning in older men ; skeletal muscle hypertrophy and improved function. J. Appl. Physiol., (1988), 64. 1038-1044.

5) Himann, J. E., David A. and peter A. Age-related changes in speed of walking, Med. Sic. Sports Exerc., (1988), 20, 161-166.

6）金子公有. 高齢者の歩行運動, Jpn. J. Sports Sci., (1991)，10, 729-733.

7）狩野 裕. ダラフィカル多変量解析, 現代数学社, 東京, (1997), 1-228.

8) Keagy, R. D., Brumlik, J., and Bergan, J. Direct elec tromyography of the psoas major muscle in man. J. Bone Joint Surg., (1966), 48, 1377-1382.
9）金 俊東，久野譜也，村上晴香，坂戸英樹，石津 政雄, 岡田守彦, 勝田 茂. 加齢に伴う大腿部の 異なる部位における筋量の変化, バイオメカニク 又研究概論, (1999), 182-185.

10）木村忠直. 加齢に伴う骨格筋の機能形態変化(1), 治療, (1996)，78，155-157.

11）久野譜也, 石津政雄, 岡田守彦, 西嶋尚彦, 松田 光生, 勝田 茂. 加齡にともなう筋萎縮における 個人差と活動量との関係, 小野スポーツ科学, (1997), 5, 47-55.

12）名倉武雄. MR 画像を用いた大腰筋の生体力学的 機能解釈，慶應医学， (1997)，74，T867-T876.

13）前田忠彦. 日本人の満足感の構造とその規定因に 関する因果モデル一共分散構造分析の「日本人の 国民性調查」への適応一，統計数理，(1995)，43， $141-160$.

14) Murray, M. P., Kory, R. C., Bertha, H. and Clarkson, B. S. Walking patterns in healthy old men. J. Gerontol., (1969), 24, 169-178.

15）岡村征一．䄃柱の筋電図学的研究一特に腰筋およ び腸骨筋の活動動態について，日大医誌，(1979）, 38, 281-298.

16）太田壽城, 小林 規, 深代千之, 高齢者の歩行に 関する研究 (第 1 報)一動的筋力および全身持久力 からみた高齢者の歩行運動一, スポーツ医・科学, (1991), 5, 31-36.

17）太田尋城, 小林 規. 高齢者の歩行に関する研究 (第 2 報)一下肢筋力から見た高齢者の歩行運動一， ス ポーツ医・科学, (1992)，6，37-41.

18) Sipila, S., Multanen, J., Kallinen, M., Era, P. and Suominen, H. Effects of strength and endurance training on isometric muscle strength and walking speed in elderly women. Acta Physiol. Scand., (1996), 156, 457-464.

19）鈴木良平. 下肢の運動力学, 日本整形外科学会雑誌, (1972), 46, 139-145.

20) Thorstensson, A., Nilsson, J. and Carlson, H. Trunk movements in human locomotion. Acta Physiol. Scand., (1984), 121, 9-22.

21）豊田秀樹, 前田忠彦, 柳井晴夫. 原因をさぐる統 計学, 講談社, 東京, (1992), 1-252.

22）渡部和彦, 塩川満久, 宮川 健. 高齢者の歩行調 整機能に関する研究 I, 体育科学, (1992), 20, 104109.

23）渡部和彦, 宮川 健. 高齢者の歩行調整機能に関 す万研究 II，体育科学，(1993)，21，239-247.

24）柳井晴夫, 繁树算男, 前川遉一. 市川雅教因子分析, 朝倉書店, 東京, (1995), 1-174。

25）山口 满. 課題解決力, 学校体育, (1998), 51, 50.

26）山本嘉一郎，小野寺孝義. Amos による共分散構造 分析と解析事例, ナカニシヤ出版，(1999)，1-21.

27）山下謙智, 中村稔堯. Gait initiation における 1 歩 目の歩速の変化と下腿筋の活動様式, 体力科学, (1990), 39, 588. 